therapy. Their hesitation is reinforced by the finding of general growth retardation and a head circumference of more than two standard deviations below the mean in six of 23 infants with a low birth weight (median age 44 weeks) who had been treated with phototherapy. There were similar findings in only one of 23 control infants (median age 47 weeks). ${ }^{9}$ The outcome of a prolonged follow-up of a larger series $^{10}$ should therefore be awaited before prophylactic phototherapy is advocated in infants with a low birth weight.

Another uncertainty is what concentration of bilirubin in the serum causes neurological damage. Though kernicterus has been shown to occur in severely asphyxiated or anoxic infants with maximum serum bilirubin concentrations of 9.4-15.6 mg/100 ml11 and of $18 \mathrm{mg} / 100 \mathrm{ml}, 12$ and retarded development at eight months was found in a poorly controlled series of infants with serum bilirubin concentrations of $16 \mathrm{mg} / 100 \mathrm{ml}$ or even less, ${ }^{13}$ much evidence suggests that in the absence of hypoxia, ${ }^{14}$ hypothermia, ${ }^{15}$ acidosis, ${ }^{16}$ and low serum albumin level ${ }^{17}$ a serum bilirubin concentration of $20 \mathrm{mg} / 100 \mathrm{ml}$ or less has no effect on subsequent I.Q.18-21 B. Wood and his colleagues ${ }^{18}$ found that the developmental assessment at one year, uncorrected for prematurity, was related to the severity of jaundice but that the I.Q. of the same infants when aged 6 was not. G. B. Odell and his colleagues ${ }^{22}$ reached somewhat similar conclusions, but made the important observation that in 32 jaundiced neonates assessed at the age of 4-7 years there was a highly significant relationship between the serum protein saturation index and abnormal cognitive findings. Such reports also support the view that routine phototherapy of premature infants, who on the above criteria have a $1 \%$ risk of requiring exchange transfusion, ${ }^{23}$ should await the outcome of adequate follow-up studies.

Phototherapy has not been very effective in controlling rapid rises in serum bilirubin, as in rhesus isoimmunization, ${ }^{24}$ but two recent reports ${ }^{25} 26$ indicate that it may be useful in A B O blood-group incompatibility. T. R. C. Sisson and colleagues ${ }^{25}$ found in a study of 35 infants (14 weighing less than $2.5 \mathrm{~kg}$ ), divided into a control (16) and a treated (19) group (matched for gestation, sex, weight, diagnosis, general health and diet), that in infants of all weights significantly lower serum bilirubin concentrations were achieved with phototherapy started when the serum bilirubin was $9.5 \mathrm{mg} / 100 \mathrm{ml}$ or more and continued until it fell below $8.5 \mathrm{mg} / 100 \mathrm{ml}$. There were no untoward effects. Five infants in the control group needed an exchange transfusion because of serum bilirubin concentrations of 16 or $18 \mathrm{mg} /$ $100 \mathrm{ml}$. E. Kaplan and colleagues, ${ }^{26}$ reviewing their experience in treating 29 cases of A B O incompatibility, concluded that it was often a mild disorder requiring no active treatment but that phototherapy was valuable when an early rise in serum bilirubin occurred and when it could be controlled within 24 hours. When the bilirubin continues to rise during this period they suggest that exchange transfusion is probably advisable.

The effective alternatives to phototherapy carry some risk. Exchange transfusion, still the mainstay in the management of hyperbilirubinaemia, has an appreciable morbidity and a mortality of $5-10 \% .{ }^{27} 28$ Phenobarbitone and other enzyme inducers can lower serum bilirubin concentrations, but their action is far from specific and subtle adverse effects may become apparent only with long-term evaluation. ${ }^{29}$ Orotic acid, a metabolic precursor of uridine diphosphate glucuronic acid (UDPGA), the glucuronide donor in bilirubin conjugation, has been given to both premature and full-term infants to lower serum bilirubin concentrations, but with conflicting results. ${ }^{30-31}$ The exciting report ${ }^{32}$ that agar lowers serum bilirubin concentrations in full-term infants by interrupting the enterohepatic circulation of bilirubin has yet to be shown to apply to infants at risk from hyperbilirubinaemia.

1 Behrman, R. E., and Hsia, D. Y. Y., Fournal of Pediatrics, 1969, 75, 718. 2 Lancet, 1970, 1, 825.

3 British Medical fournal, 1970, 2, 5.

4 Schmid, R., New England fournal of Medicine, 1971, 285, 520.

5 Bilirubin Metabolism in the Newborn, ed. D. Bergsma and D. Y. Y. Hsia. Baltimore, Williams \& Wilkins, 1970.

- Ostrow, J. D., Fournal of Clinical Investigation, 1971, 50, 707.

7 Cremer, R. J., Perryman, P. W., and Richards, D. H., Lancet, 1958, 1,

8 Lucey, J. F., in Bilirubin Metabolism in the Newborn, ed. D. Bergsma and D. Y. Y. Hsia, p. 63. Baltimore, Williams \& Wilkins, 1970.

- Hodgman, J. E., and Teberg, A., in Bilirubin Metabolism in the Newborn, ed. D. Bergsma and D. Y. Y. Hsia, p. 75. Baltimore, Williams \& Wilkins, 1970

10 Warren, C. B. M., and Broughton, P. M. G., British Medical fournal, $1970,11,299$.

11 Gartner, L. M., Snyder, R. N., Chabon, R. S., and Bernstein, J., Pediatrics, $1970,45,906$.

12 Ackerman, B. D., Dyer, G. Y., and Leydorf, M. M., Pediatrics, 1970, 45,918 .

13 Boggs, T. R., Hardy, J. B., and Frazier, T. M., fournal of Pediatrics, 1967, $1,553$.

14 Lucey, J. F., Hibbard, E., Behrman, R. E., Esquivel de Gallardo, F. O., and Windle, W. F., Experimental Neurology, 1964, 9, 43.

15 Stern, L., and Doray, B. E., Proceedings of the 12 th International Congress of Pediatrics, Mexico City, Abstract No. 464, 1968.
.

16 Diamond, I., and Schmid, R., Fournal of Clinical Investigation, 1966, 45,

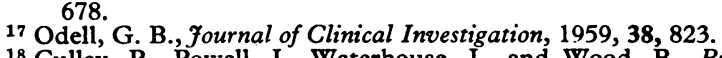

18 Culley, P., Powell, J., Waterhouse, J., and Wood, B., British Medical Fournal, $1970,3,383$.

19 Johnston, W. H., et al., Pediatrics, 1967, 39, 88.

20 Holmes, G. E., Miller, J. B., and Smith, E. E., American fournal of Diseases of Children, 1968, 116, 37.

21 Stewart, R. R., Walker, W., and Savage, R. D., Developmental Medicine and Child Neurology, $1970,12,16$.

22 Odell, G. B., Storey, G. N. B., and Rosenberg, L. A., fournal of Pediatrics, $1970,76,12$.

28 Davies, P. A., Lancet, 1969, 2, 273.

24 Sisson, T. R. C., et al., Pediatric Research, 1969, 3, 380.

25 Sisson, T. R. C., Kendall, N., Glanser, S. C., Knutson, S., and Bunya-

${ }^{26}$ Kaplan, E., Herz, F., Scheye, E., and Robinson, L. D., fournal of Pediatrics, $1971,79,91 \dot{1}$.

27 Kitchen, W. H., Australian Paediatric fournal, 1970, 6, 30.

28 Wilson, J. T., Pediatrics, 1969, 43, 324.

2 Matsuda, I., and Shirehata, T., Tohoku fournal of Experimental Medicine, $1966,90,133$.

${ }^{30}$ Gray, D. W. G., and Mowat, A. P., Archives of Disease in Childhood, 1971, 46, 123.

${ }^{31}$ Schwarze, R., Kintzel, H. W., and Hinkel, G. K., Acta Paediatrica Scandinavica, 1971, 60, 705.

s2 Poland, R. L., and Odell, G. B., New England Fournal of Medicine, 1971, 284,1 .

\section{A Career Structure for Cancer Research}

One of the main developments reported by the Imperial Cancer Research Fund ${ }^{1}$ is the establishment under Professor G. Hamilton Fairley at St. Bartholomew's Hospital of an extramural unit of medical oncology for research into the clinical aspects and treatment of the lymphomas and leukaemias. This development is significant in its own right, but it also has a wider importance, as the Fund's chairman, Professor E. F. Scowen, points out.

At present clinical cancer research lacks a career structure and tends to depend on a series of doctors and scientists undertaking research during their progress to other posts in medicine or science. To make full use of people and their ideas the possibility of full training in both laboratory and clinical methods must be available. In addition, "There must be a career structure in which workers can develop and mature if the first-class brain is to be attracted and main- 
tained in the problems of cancer research." This recognition by one of the two larger charities concerned with cancer research in Britain of the need for a career structure is long overdue and should help to attract first-class brains to cancer research. At the same time it is a contradiction of the misleading, if not untruthful, view that a complete solution to the myriad of cancer problems lies only just out of reach of a single brilliant or lucky scientist and that, given more money, contact with this hypothetical solution might be made in the next year or so. It is to be hoped, therefore, that the new unit at St. Bartholomew's Hospital will both flourish and serve as a model for future specialized regional oncology centres within the hospital service.

Dr. M. G. P. Stoker explains his dilemma as director of research in the Fund's own laboratories. Though the aims of cancer research remain clear, the best means of achieving them among an ever increasing range of ways of spending cancer research funds are not. There are those who believe that the best hope lies in obtaining a deeper understanding of living processes. Others press for a more fullhearted and rational use of existing knowledge of cancer causation and therapeutic methods. Stoker sees no alternative but to steer a course between these extreme views. The appointment of Dr. Renato Dulbecco, of the Salk Institute for Biological Studies, as assistant director is significant in this connexion. Dulbecco's experience of the use of quantitative techniques in relation to tumour virology and his interest in differences between cell membrane in normal and cancer cells will extend the Fund's interest and ability to contribute to the fundamental understanding of this aspect of living systems. Work already in progress has shown that three types of glycolipid which are present in abundance on the surfaces of normal non-dividing cells are present in reduced amounts on the surfaces of rapidly dividing normal cells and absent from the surfaces of a wide variety of cells transformed by various cancer viruses. ${ }^{23}$ It is not yet certain whether these changes account for the difference in behaviour between normal and transformed cells, or whether they are merely a non-specific consequence of malignant transformation.

The value of experimental hybridization of somatic cells in the study of the formal genetics of man was increased by the discovery 4 that in man-mouse cell hybrids human chromosomes are gradually lost to the point of their complete elimination. Enzyme studies on cells in the penultimate stage of this process-that is, cells containing a complete set of mouse chromosomes but only one human chromosome-are beginning to provide detailed human genetic information. Dr. G. Pontecorvo ${ }^{5}$ at the Fund's laboratories recently developed a technique, involving the prior exposure of one or other parent cell to ionizing radiation, for determining which set of chromosomes will be preferentially eliminated from a somatic cell hybrid. Prior exposure of one of the parent cells to 5-bromodeoxyuridine has also been reported to predispose to the preferential elimination of chromosomes from somatic cell hybrids. 6

The long-term study of R. D. Bulbrook, J. L. Hayward, and others ${ }^{7}$ aimed at characterizing women at special risk of developing cancer of the breast, hitherto limited to the Island of Guernsey, is to be extended to involve some 50,000 women in London. The latest results from the Guernsey study have indicated that a simple measurement of a single hormone product in the urine is a useful indicator of high risk of breast cancer.

The retirement of Mr. Dickson Wright as treasurer of the Fund is a sad but notable event. During the 20 years of his stewardship the Fund's income has risen 20-fold in response to his energy, wit, and powers of persuasion. Just over $£ 1 \mathrm{~m}$. was spent on research during 1971, while the total assets rose by over $£ 2 \mathrm{~m}$. to $£ 13,250,000$.

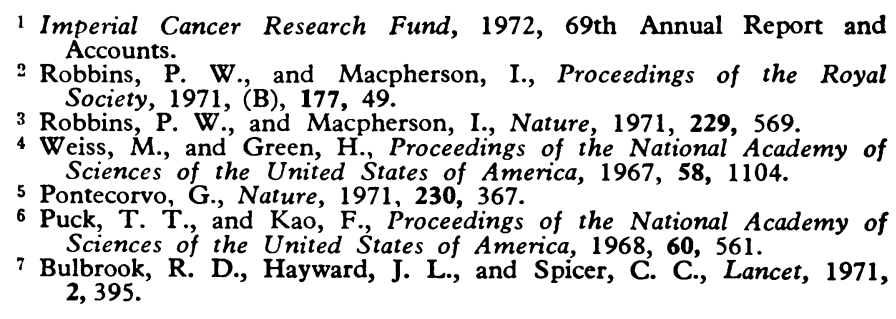

\section{Sound and Fury}

Private practice has for many years formed only a small part of medicine in Britain. Nevertheless, among doctors and politicians-and especially the latter-the subject tends to raise an amount of sound and fury quite disproportionate to its size. What patients really think about private medicine is hard to discern but a sufficient number of them sought it to provide the N.H.S. hospitals with an estimated income of nearly $£ 11 \mathrm{~m}$. in $1971-2$, while the provident associations have shown a consistent increase in subscription incomes over the years and now collect around $£ 18 \mathrm{~m}$. annually. Furthermore, according to a parliamentary report on N.H.S. Facilities for Private Patients' just published, "fees from the private sector must equal about $12 \%$ of total N.H.S. remuneration for medical and professional staff and an even higher proportion for consultants alone."

This report-its conclusions and recommendations are published in the Supplement (p. 12)-was the work of the Social Services Subcommittee of the Parliamentary Expenditure Committee, and its inquiry with Mrs. Renée Short in the chair started before the present administration took office. Given that an inquiry into private practice in the Service was necessary-and with all the other pressing problems facing the N.H.S. this is doubtful-it is an insubstantial report. Perhaps this is an accurate reflexion of the importance of the issue, which after all involves resources equivalent to only $1 \%$ of the total cost of the N.H.S. Nevertheless, the volume of written and verbal evidence was truly formidable, though some of it (particularly the critical submissions) contained much froth and little body.

The report's final form was determined by the political balance of power, and the Expenditure Committee's debate on it shows that had the Opposition been in office the report's conclusions and recommendations would have been quite different. As it is, the report will be seen by most doctors as confirming what they thought already-namely, that "Private practice operates to the overall benefit of the N.H.S.," as the report puts it. Certainly so long as sufficient patients want private care there should be no bar-and indeed every encouragement-to its being practised in concert with the Health Service. In return for this sensible and mutually beneficial arrangement, doctors should try to ensure that abuses do not occur. In this respect the report's proposal "that control procedures in hospitals should be more strictly observed" is reasonable, though the Department of Health in its evidence appreciated that "if one 